BENM 2021

International Scientific and Practical Conference "Biotechnology, Ecology, Nature Management"

\title{
HYDROCHEMICAL PARAMETERS OF GROWING TROUT ON WATER FROM AN ARTESIAN WELL
}

\author{
A. K. Ponomarev (a)*, L. L. Brezhnev (b), V. A. Klimov (c), A. S. Polyakov (d) \\ *Corresponding author
}

(a) K.G. Razumovsky Moscow State University of Technologies and Management (the First Cossack University), 73, Zemlyanoy Val str., Moscow, Russia, ponomarev777@mail.ru

(b) K.G. Razumovsky Moscow State University of Technologies and Management (the First Cossack University), 73, Zemlyanoy Val str., Moscow, Russia

(c) K.G. Razumovsky Moscow State University of Technologies and Management (the First Cossack University), 73, Zemlyanoy Val str., Moscow, Russia, v.klimov@mgutm.ru

(d) K.G. Razumovsky Moscow State University of Technologies and Management (the First Cossack University), 73, Zemlyanoy Val str., Moscow, Russia, alexey-31@yandex.ru

\begin{abstract}
Maintaining the quality of hydrochemical parameters during trout farming in open farms is one of the key tasks of aquaculture. This article examines the hydrochemical composition of well water and determines its suitability for commercial breeding of rainbow trout (Oncorhynchus mykiss). It is also noted in the article that trout breeding on water from artesian springs has many advantages, such as: constant hydrochemical composition of water, microbiological purity and optimal temperature for growing marketable trout in the summer in the middle latitude of the Russian Federation, in contrast to pond farms where the geographical location of the economy and the qualitative composition of the water have a large weight, since not all terrestrial reservoirs are suitable for breeding trout. The data obtained allow us to confirm that the use of groundwater in rainbow trout aquaculture as a source of water is possible if the appropriate purification. Specific attention should be paid to the content of magnesium, iron, and potassium.
\end{abstract}

2672-8575 (C) 2022 Published by European Publisher.

Keywords: Artesian water, hydrochemistry, trout, water quality 


\section{Introduction}

In Russia, cold water aquaculture is gaining more and more popularity, the main object of which is rainbow trout. According to official data, the volume of commercial trout production in the territory of the Republic of Karelia in 2019 increased by more than 20\% compared to 2018 and amounted to 22 thousand tons (Marynych \& Kolmykov, 2016). The recognized centers of trout breeding are Denmark, France, Italy, where 140 - 180 thousand centners of this fish are grown annually (Artamonov, 2010; Zelennikov et al., 2019).

Rainbow trout is widely cultivated both in RAS and in natural cold water bodies. Due to its fishbreeding qualities, it adapts well to artificial conditions of keeping and assimilates artificial feed, has a high growth rate at a high stocking density in comparison with other cold-water commercial fish farming objects. Trout is resistant to many abiotic factors, but it is demanding on water quality (Madeev et al., 2017).

The optimal range of water temperature for growth and development is 10 - 18 degrees. Of the traditional objects of commercial fish farming in the Russian Federation, trout is more demanding on the oxygen content in water - the optimal range of the dissolved oxygen content is the concentration of 7-9 $\mathrm{mg} / 1$, a decrease to 3-4 mg / 1 causes depression and death (Zharkenov et al., 2017)

The optimum temperature for dilution in salt water is 8 to $20^{\circ} \mathrm{C}$. Adult rainbow trout can tolerate ocean salinity up to $35 \%$ o. Fish with a marketable weight of 250-500 g feels good at 20-30 \%o. (Grigoriev \& Sedova, 2008).

The $\mathrm{pH}$ should be close to neutral values and not go beyond 6.5-8.5 pH. (Zharkenov et al., 2017)

The permissible concentration of ammonia in water is $0.1 \mathrm{mg} / 1$. Ammonia content equal to 0.3$0.4 \mathrm{mg} / 1$ causes the death of trout. The content of nitrites, the products of intermediate metabolism, which reduce the growth rate and survival of fish, should not exceed $0.08 \mathrm{mg} / 1$. An increase in nitrite concentration up to $0.5 \mathrm{mg} / 1$ leads to the death of fish (Zharkenov et al., 2017). The permissible concentration of chlorides in freshwater reservoirs where rainbow trout is grown is up to $20 \mathrm{mg} / 1$. The optimal concentration of sulfates is up to $5 \mathrm{mg} / 1$, total iron - up to $1 \mathrm{mg} / 1$. Water hardness, which is most optimal for trout breeding, is 3.0-4.3 meq / 1 (Kuznetsov et al., 2017; Lazarev et al., 2020).

Breeding trout on water from artesian springs has many advantages, such as: constant hydrochemical composition of water, microbiological purity and optimal temperature for growing marketable trout in the summer in the middle latitude of the Russian Federation, in contrast to pond farms where the geographic location of the economy has a large weight and the qualitative composition of the water, since not all terrestrial reservoirs are suitable for trout breeding.

It should also be noted that in rare cases it may be necessary to adjust the hydrochemical parameters of artesian water through a system of mechanical and biological filters (Nikiforov-Nikishin et al., 2020; Zelennikov, 2019)

\section{Purpose of the Study}

There was a need to study the hydrochemical parameters of artesian water for compliance with fishery standards, which was carried out on the basis of a fish-breeding enterprise in the Belgorod region, 
in which trout is grown in concrete cascade pools with running water from an artesian well. The object of the study was water and its hydrochemical indicators for compliance with water quality standards for fishery water bodies.

\section{Research Methods}

Water samples were taken at the inlet and outlet of the fish-breeding ponds, the analysis of the samples was carried out using the hosted methods, the data obtained were compared with the approved standards.

Table 1 shows the results of the analysis of water from a well at the entrance to fish-breeding basins. According to the results, one can notice the presence of substances of the nitrogen group and phosphates, their presence due to the mixing of circulating water.

Table 1. Results of analysis of water from the well at the entrance to the fish-breeding basin

\begin{tabular}{|c|c|c|c|}
\hline Quality indicator, units & $\begin{array}{l}\text { Measurement } \\
\text { result }\end{array}$ & $\begin{array}{l}\text { MPC for } \\
\text { fishery }\end{array}$ & $\begin{array}{l}\text { normative documents for the measurement } \\
\text { procedure }\end{array}$ \\
\hline \multicolumn{4}{|c|}{ Organoleptic indicators of water quality } \\
\hline Odor at $20 \mathrm{C}^{\mathrm{o}}$, points & 1 & - & GOST 3351-74 \\
\hline Color, degrees & 2 & - & GOST 3351-74 \\
\hline Turbidity, EMF & 1 & - & GOST 3351-74 \\
\hline \multicolumn{4}{|c|}{ Indicators of the chemical composition of water } \\
\hline Hydrogen exponent $(\mathrm{pH})$ & 7,6 & $6,5-8,5$ & PND F 14.1: $2: 3: 4.121-97$ \\
\hline Hydrocarbonates, mg / 1 & 487 & - & GOST 31957-2012 \\
\hline Total alkalinity, mmol / 1 & 8 & - & GOST 31957-2012 \\
\hline Total hardness, coolant & 13 & - & GOST 31954-2012 \\
\hline $\begin{array}{l}\text { Total mineralization (dry } \\
\text { residue), } \mathrm{mg} / \mathrm{l}\end{array}$ & 484 & $\begin{array}{l}\text { No more } \\
1000\end{array}$ & PND F 14.1: 2: 4.114-97 \\
\hline Free chlorine, mg / 1 & $<0,1$ & 0,00001 & MVI 01.00225 / 205-18-11 \\
\hline Total chlorine, $\mathrm{mg} / \mathrm{l}$ & $<0,1$ & - & MVI 01.00225 / 205-18-11 \\
\hline $\begin{array}{c}\text { Ammonium (nitrogen), } \mathrm{mg} \\
\text { / } 1\end{array}$ & 0,33 & 0,5 & MVI 101-08 \\
\hline $\begin{array}{l}\text { Permanganate oxidizability, } \\
\qquad \mathrm{mgO} / \mathrm{dm} 3\end{array}$ & $<0,25$ & - & PND F 14.1: 2: 4.154-99 \\
\hline Nitrates, mg / 1 & 2,2 & 40 & MVI 16-09 \\
\hline Sulfates, mg / 1 & $>70(92)$ & 100 & MVI 6-10 \\
\hline Nitrite, mg / 1 & 0,02 & 0,08 & MVI 69-09 \\
\hline Polyphosphates, mg / 1 & 0,08 & - & MVI 25-10 \\
\hline Iron, mg / 1 & 0,016 & 0,1 & GOST 31870-2012 \\
\hline Copper, mg / 1 & $<0,002$ & 0,001 & GOST 31870-2012 \\
\hline Lead, mg / 1 & $<0,002$ & 0,06 & GOST 31870-2012 \\
\hline Calcium, mg / 1 & 146 & 180 & GOST 31870-2012 \\
\hline Magnesium, mg / 1 & 19 & 40 & GOST 31870-2012 \\
\hline
\end{tabular}

According to table 2, it can be noted that the color index increased by 1 point, the maximum permissible concentration for ammonium was 3 times exceeded, the content of nitrates (by $1.2 \mathrm{mg} / 1$ ), nitrites (by 0,02 $\mathrm{mg} / \mathrm{l}$ ) and polyphosphates by 3.5 times, such an increased content is the result of feeding the fish and the remains of trout waste products. 
Table 2. Results of analysis of water at the outlet of the fish tank

\begin{tabular}{|c|c|c|c|}
\hline Quality indicator, units & $\begin{array}{l}\text { Measurement } \\
\text { result }\end{array}$ & $\begin{array}{l}\text { MPC for } \\
\text { fishery }\end{array}$ & $\begin{array}{c}\text { normative documents for the measurement } \\
\text { procedure }\end{array}$ \\
\hline \multicolumn{4}{|c|}{ Organoleptic indicators of water quality } \\
\hline Odor at $20 \mathrm{C}^{\circ}$, points & 1 & - & GOST 3351-74 \\
\hline Color, degrees & 3 & - & GOST 3351-74 \\
\hline Turbidity, EMF & 1 & - & GOST 3351-74 \\
\hline \multicolumn{4}{|c|}{ Indicators of the chemical composition of water } \\
\hline Hydrogen exponent $(\mathrm{pH})$ & 7,9 & $6,5-8,5$ & PND F 14.1: $2: 3: 4.121-97$ \\
\hline Hydrocarbonates, mg / 1 & 487 & - & GOST 31957-2012 \\
\hline Total alkalinity, mmol / 1 & 8 & - & GOST 31957-2012 \\
\hline Total hardness, coolant & 11,2 & - & GOST 31954-2012 \\
\hline $\begin{array}{l}\text { Total mineralization (dry } \\
\text { residue), } \mathrm{mg} / 1\end{array}$ & 477 & $\begin{array}{l}\text { Не более } \\
1000\end{array}$ & PND F 14.1: 2: 4.114-97 \\
\hline Free chlorine, $\mathrm{mg} / 1$ & $<0,1$ & 0,00001 & MVI 01.00225 / 205-18-11 \\
\hline Total chlorine, mg / 1 & $<0,1$ & - & MVI $01.00225 / 205-18-11$ \\
\hline $\begin{array}{c}\text { Ammonium (nitrogen), } \mathrm{mg} \\
/ / 1\end{array}$ & 1,2 & 0,5 & MVI 101-08 \\
\hline $\begin{array}{l}\text { Permanganate oxidizability, } \\
\mathrm{mgO} / \mathrm{dm} 3\end{array}$ & $<0,25$ & - & PND F 14.1: 2: 4.154-99 \\
\hline Nitrates, $\mathrm{mg} / \mathrm{l}$ & 3,3 & 40 & MVI 16-09 \\
\hline Sulfates, $\mathrm{mg} / 1$ & $>70(96)$ & 100 & MVI 6-10 \\
\hline Nitrite, mg / 1 & 0,04 & 0,08 & MVI 69-09 \\
\hline Polyphosphates, mg / 1 & 0,28 & - & MVI 25-10 \\
\hline Iron, mg / 1 & 0,020 & 0,1 & GOST 31870-2012 \\
\hline Copper, mg / 1 & $<0,002$ & 0,001 & GOST 31870-2012 \\
\hline Lead, mg / 1 & $<0,002$ & 0,06 & GOST 31870-2012 \\
\hline Calcium, mg / 1 & 144 & 180 & GOST 31870-2012 \\
\hline Magnesium, mg / 1 & 19 & 40 & GOST 31870-2012 \\
\hline
\end{tabular}

\section{Findings}

Based on the data obtained, it can be concluded that the water fully complies with the norms established by laws in accordance with the order of December 13, 2016 N 552 On the approval of water quality standards for fishery water bodies, including standards for maximum permissible concentrations of harmful substances in the waters of fishery water bodies ... (On Approval of Water Quality Standards...).

\section{Conclusion}

Thus, the article discusses the main regulatory documents regulating the quality of water for fishery activities. The data obtained allow us to draw a conclusion about the possible use of artesian water in other regions for growing trout.

\section{Acknowledgments}

This work was carried out as part of the participant's activities world-class scientific and educational center "Innovative solutions in the agro-industrial complex" (Belgorod region) 


\section{References}

Artamonov, V. O. (2010). Trout breeding development in the Republic of Karelia. Organizers of the II Youth Economic Forum, 1, 115-116.

Grigoriev, S. S., \& Sedova, N. A. (2008). Prospects for commercial salmon farming in Kamchatka. Fish farming and fish farming, 12, 2-6.

Kuznetsov, M. Yu., Piltyaeva, V. V., \& Kuznetsova, T. A. (2017). Research of hydrochemical composition of water during trut breeding. Safety and quality of agricultural raw materials and food, $1,157-161$.

Lazarev, V. I., Lazareva, R. I., Shatokhin, M. V., \& Glebova, I. A. (2020, February). The Sources of Income and the Dynamics of Heavy Metals in the Soil of Different Agro-Ecosystems with Their Long-Term Agricultural Use. In IOP Conference Series: Materials Science and Engineering (Vol. 753, No. 6, p. 062030). IOP Publishing. https://doi.org/10.1088/1757-899X/753/6/062030

Madeev, S. A., Savelyeva, I. S., \& Bogdanova, Yu. Z. (2017). Trout breeding. Topical issues of science and economy: new challenges and solutions, 1, 198-200.

Marynych, S. N., \& Kolmykov, S. N. (2016). Mineral underground waters in the Belgorod region. Modern trends in the development of science and technology, 3(2), 95-98.

Nikiforov-Nikishin, A. L., Nikiforov-Nikishin, D. L., Kochetkov, N. I., \& Tatarenko, P. Y. (2020, August). Biocenosis of cold-water and warm-water biofilter in recirculating aquaculture system. In IOP Conference Series: Earth and Environmental Science (Vol. 548, No. 8, p. 082097). IOP Publishing. https://doi.org/10.1088/1755-1315/548/8/082097

Zelennikov, O. V., Kuznetsov, Y. K., \& Fedorov, K. E. (2019). Features of the formation of the structure and volume of the fund of previtellogenic oocytes in rainbow trout. Trudy Vniro, 175, 76-85. https://doi.org/10.36038/2307-3497-2019-175-76-85

Zharkenov, D. K., Nevalennyi, A. N., Isbekov, K. B., Asylbekova, S. Zh., Sadykulov, T. S., Anuarbekov, S. M., \& Badryzlova, N. S. (2017). Trout cultivation technology at the Tainta reservoir in the East Kazakhstan region. Bulletin of the Astrakhan State Technical University. Series: Fisheries, 4, 8594. 